\title{
Processamento Eletrônico de Dados e Outros Auxílios Tecnológicos
}

ABGAR RENAULT

Presidente do Tribunal de Contas da União

A necessidade de computação, em auditoria, tem as suas raizes em quatro fatos: a sempre crescente complexidade da auditoria; o ritmo lento dos seus serviços atuais, nos quais encontramos um mínimo de eficiência e um máximo de processos consumidores de tempo em alta escala; a falta de exatidão de tais processos; e a economia de brain-power que seguramente advirá da implantação de novos métodos.

Isto se verifica no caso especial do Brasil, e pode estender-se a todos os países nos quais a automatização ainda não abriu o seu caminho até a auditoria.

Há alguns campos, é óbvio, em que o uso de computadores ainda se encontra no nascedouro, e os seus resultados são duvidosos. O computador literário é um dêsses exemplos. Não é de surpreender, por exemplo, que as tentativas de criar poesia tenham revelado a impossibilidade de produzir sentenças com estruturas diferentes das analisadas. Ainda os melhores poemas - segundo fomos informados - produzidos entre mithares, eram menos interessantes em si próprios, do que pelo fato de, pela sua ilogicidade e obscuridade, nos levarem de volta aos problemas estéticos tradicionais.

Por outro lado, sessenta e quatro participantes de nove países que se reuniram no ano passado em Cambridge, para um simpósio de três dias, debateram e discutiram mais de 30 pequenos relatórios sôbre projetos de pesquisa em andamento, chegando a uma conclusão, que pode ser de importância quanto ao uso de programas de computador no campo da auditoria, no relativo aos princípios legais aplicados a orçamento, relatórios oficiais, processos etc., qual seja: a precisão lógica exi- 
gida dos pronunciamentos legais é admiràvelmente apropriada para a forma de análise sintática para processamento em computador.

Assim, não é de admirar que a maioria dos programas de computador possa dar ao auditor a capacidade de desempenhar importantes tarefas, tais como computação, verificação, separação, comparação, seleção, resumo e amostragem por meio do uso da velocidade e da exatidão do computador. Quanto aos aspectos econômicos, seja suficiente dizer que a análise de um computador usado pela "The San Francisco Regional Office, California", demonstrou que um programa para o contrôle dos pagamentos a médicos por visitas domiciliares, de acôrdo com os programas Federal Medicare e State Medicaid tiveram o custo de US\$1,600 contra US $\$ 9,600$, isto é, a economia foi estimada em US $\$ 8,000$. O custo da mesma operação pelos métodos tradicionais seria, medido em homensdia de trabalho, proibitivo.

Conseguimos avaliar as diferenças de tempo em duas operações essenciais do Tribunal de Contas da União. São as seguintes: a) o contrôle destinado a apurar se as contas de 3.951 municípios e os respectivos planos de aplicação das importâncias da ajuda federal está, presentemente, com um atraso de cêrca de mês e meio, o que equivale a dizer que não é possível saber, no prazo da lei, o que deverá ser sabido; um computador nos dará a resposta em cêrca de dez minutos, após o encerramento do prazo para encaminhamento de tais documentos; b) o contrôle das importâncias pagas mediante autorização do Tribunal de Contas às municipalidades consome o trabalho de três funcionários durante todo o ano; entretanto, o computador levará cêrca de 24 horas por ano para efetuar a mesma tarefa.

A exatidão depende fundamentalmente da qualidade dos dados com que se alimenta o computador, o que, por sua vez, depende da qualificação do pessoal que prepara tais dados. Vale lembrar o ditado comumente ouvido na América, segundo o qual, se alimentarmos o computador com lixo, êle nos devolverá lixo.

Nenhum auditor necessita ter mais do que um conhecimento geral do computador, suas necessidades e problemas. Não há absolutamente qualquer necessidade de que conheça as operações relativas ao seu funcionamento.

Não obstante, não se podē dizer que a ajuda de homens habilitados possa ser dispensada para as operações do compu- 
tador, no sentido de alimentá-lo corretamente e receber dêle resultados exatos.

No seu notável "Management Planning for Data Processing", Dick H. Brandon afirma que mais de $30 \%$ de todos os sistemas de processamento de dados dos Estados Unidos representam um completo fracasso, e a maioria de tais fracassos deve ser atribuída à incapacidade dos responsáveis administrativos de darem o necessário apoio à atividade de processamento de dados ou de interessarem-se suficientemente pelo problema.

Algumas das indagações cruciais que esta matéria levanta são as seguintes: é o processamento eletrônico de dados utilizado o mais adequado para cada caso? Que conseqüências econômicas advirão da sua implantação? Como deverá a sua instalação e funcionamento ser planejada? De que tipo de informação necessita a administração no sentido de fazer funcionar o nôvo processo? Quem deverá cuidar de tais problemas?

A máquina é, certamente, falha sem a presença do homem.

É oportuno esclarecer que, no caso específico do Tribunal de Contas da União, não se pode pensar na compra de um computador. Tal equipamento custaria soma de dinheiro muito elevada e permaneceria ocioso a maior parte do tempo, e, ain$\mathrm{da}$, ràpidamente tornar-se-ia inatual. A solução adequada será alugar os serviços de uma companhia de reconhecida reputação. Esta foi a diretriz por que optamos.

Tôdas as unidades do Tribunal receberão grande benefício com a introdução de um sistema de microfilmes projetado para substituir o sistema de arquivo de milhares de processos, documentos e papéis de tôda natureza. Isto significa que uma fôlha de papel do tamanho médio de $33 \times 22 \mathrm{~cm}$ será reduzida pelo menos 40 vêzes em seu tamanho, isto é, $8,3 \mathrm{~mm} \times 5,5 \mathrm{~mm}$, - que economizará espaço correspondente nos arquivos.

Com respeito à utilização de processamento eletrônico de dados na administração pública brasileira, os seguintes pontos merecem ser mencionados:

(Serviço 1964, uma emprêsa pública com a sigla "SERPRO" - objetivo primár de Processamento de Dados) foi criada com zenda ao qual permo de prestar serviços ao Ministério da Fa- 
O campo de ação dessa emprêsa foi ampliado consideràvelmente e, atualmente, foi-lhe permitido prestar serviços, sob contrato, a qualquer outra repartição federal, estadual ou municipal.

$\mathrm{Na}$ área do Ministério da Fazenda, todo o trabalho da Divisão da Receita relativo a cobrança, arrecadação e processamento contábil dos impostos federais já está sendo computado eletrônicamente pela emprêsa em questão.

O "SERPRO" processa, atualmente, mais de $60 \%$ das fôIhas de pagamento de tôdas as repartições federais. Pode-se prever uma grande expansão de suas atividades devida ao considerável número de levantamentos técnicos a que se está procedendo a pedido de órgãos governamentais interessados no uso do auxílio do computador.

É, ainda, importante mencionar que o "SERPRO" iniciará em breve o funcionamento de um "Centro de Treinamento Nacional de Computação", o qual terá como objetivo principal a administração de cursos sôbre programação, análise e tôdas as outras técnicas relativas ao processamento eletrônico de dados para funcionários públicos, pessoas com cursos universitários e outras devidamente qualificadas, a fim de fazer face à crescente procura de mão-de-obra especializada nesse campo.

$\mathrm{Na}$ área da administração indireta, cabe pôr em relêvo que algumas entidades de elevada importância e grande volume de trabalho instalaram os seus próprios sistemas de processamento, na maioria dos casos, tanto para fins administrativos internos como para uso nas suas operações externas. Entre elas, cabe mencionar as seguintes:

- "Instituto Nacional da Previdência Social" (INPS);

- "Caixa Econômica Federal" (CEF);

— "Rêde Ferroviária Federal" (RFFSA);

— "Banco do Brasil";

- "Banco Central do Brasil";

- "Emprêsa Brasileira de Telecomunicações" (EMBRATEL); e

- "PETROBRÁS".

O contrôle externo das finanças públicas no Brasil é, em última análise, da competência do Congresso Nacional, missão em que é auxiliado pelo Tribunal de Contas da União, o qual 
possui organização colegiada e é composto de nove Ministros que decidem por voto.

Essa instituição encara a introdução do processamento automático de dados nos seus serviços como uma necessidade urgente, para fazer face ao volume crescente do seu trabalho e para assegurar altos níveis de eficiência, velocidade, exatidão e economia.

Estudos preliminares já estão sendo levados a efeito, tanto pelo "Serviço Federal de Processamento de Dados" como por uma emprêsa privada. A computação eletrônica expandirse-á gradualmente, até que possa cobrir tôdas as áreas apropriadas para automatização.

A Secretaria do Tribunal, que tem a seu cargo a execução de tôdas as operações referentes ao contrôle das finanças públicas, está dividida em diversas unidades, de acôrdo com a natureza de serviços nelas executados, e compreende uma Diretoria Administrativa e sete Diretorias Técnicas.

\section{DIRETORIA ADMINISTRATIVA}

Dentro da Diretoria Administrativa, além da Seção de Pessoal, a qual já tem as suas fôlhas de pagamento preparadas pelo "Serviço Federal de Processamento de Dados" mencionado, o "Serviço de Comunicações" merece especial atenção.

Os seguintes pontos são dignos de menção:

Natureza do Trabalho Executado - recebimento, numeração, anotação, fichamento e distribuição de todos os processos e documentos submetidos ao Tribunal;

pondência;

cum - anotação do movimento de todos os processos e do-

- fornecimento de informações a qualquer pessoa ou repartição governamental, bem como às outras unidades do Tribunal, com respeito ao andamento de todos os processos e de quaisquer documentos enviados ao Tribunal, e sua exata localização, a qualquer tempo. O volume dêsse trabalho atingiu, em 1970, o total de 137.378 unidades.

Em face da grande quantidade de dados com que lida 0 "Serviço de Comunicações", decorrente do alto número de documentos recebidos pelo Tribunal, poder-se-ia obter uma re- 
dução substancial no número de homens-hora necessário para o desempenho adequado de tais funções por meio da computação eletrônica.

Pretende-se introduzir o processamento de dados, nessa área, dentro de uma estimativa que poderemos classificar como de curto prazo.

A análise preliminar que está sendo feita indica que o uso da automatização nessa dependência poderia imediatamente beneficiar tôdas as outras unidades da Côrte, especialmente no que diz respeito ao contrôle dos prazos para encaminhamento de certos processos, como é o caso de 3.951 municipalidades que têm de submeter as suas contas até o dia 30 de abril, sob pena de suspensão da entrega dos recursos federais que Ihe são concedidos, até que tal documentação seja enviada. (Ver item relativo à 1 a Diretoria Técnica).

Até o presente, a apuração, no devido tempo, de tôdas as municipalidades que não têm cumprido tal exigência, para efeito de ordenarem-se as medidas necessárias, tem sido prejudicada, em muitos casos, pela falta de meio eficiente para manipular tão grande número de processos e os dados respectivos, a uma velocidade razoável.

\section{DIRETORIAS TÉCNICAS}

Cada uma das sete Diretorias Técnicas tem sob sua responsabilidade determinada área da Administração Pública sujeita ao contrôle externo do Tribunal de Contas da União.

Exceto a 1ạ Diretoria Técnica, encarregada de determinados Fundos Federais concedidos aos Estados, ao Distrito Federal, aos Municípios e aos Territórios Federais, e a 5 a Diretoria Técnica, à qual estão afetas as aposentadorias, reformas e pensões, as restantes cinco Diretorias têm sob sua responsabilidade áreas da Administração Federal Direta ou Indireta.

\section{DIRETORIA TÉCNICA}

Natureza do Trabalho Executado - Esta Diretoria tem sob sua responsabilidade o contrôle das importâncias deduzidas da arrecadação de certos impostos federais que compõem os "Fundos de Participação dos Municípios e os Fundos de Participação dos Estados e do Distrito Federal e dos Territórios".

Deve ser lembrado que, além de controlar a aplicação dêsses montantes, o Tribunal de Contas tem a seu cargo o esta- 
belecimento das porcentagens dos Fundos devidas a cada Municipalidade, Estado ou Território e a autorização de seu pagamento pelo Banco do Brasil.

Essa missão, confiada ao Tribunal pela Constituição Federal, vai além das suas atribuições normais de contrôle e representa uma exceção.

Além de inspeções in loco, o trabalho por essa unidade levado a efeito na Sede do Tribunal pode ser dividido nas seguintes operações básicas:

1 - Fixação das porcentagens e autorizações da liberação das quotas

a) Cálculo das porcentagens devidas a cada Município (num total de 3.951), a cada Estado (23) e a cada Território (3), baseado na população, área e renda per capita de cada um dêles;

b) Informação ao Banco do Brasil, até o dia 31 de dezembro de cada ano, sôbre as porcentagens que deverão ser observadas na entrega mensal dos valôres devidos a cada Unidade.

\section{2 - Contrôle da aplicação dos Fundos}

a) Ordem ao Banco do Brasil para suspensão da entrega dos valôres devidos às Unidades que não tenham submetido, até 30 de abril, suas contas referentes à aplicação das quotas do Fundo, bem como os seus planos estimativos de aplicação dos valôres a serem concedidos no ano seguinte;

b) Exame dos seguintes documentos referentes a cada uma das 3.951 Unidades mencionadas no item I a):

b. 1) Balanço Financeiro; Balanço Patrimonial e Balanço Orçamentário, com os respectivos demonstrativos de execução orçamentária;

b.2) Demonstrativo da execução do Plano de Aplicação dos recursos do Fundo;

b.3) Cópia do demonstrativo detalhado da aplicação dos recursos do fundo, publicado na imprensa local, para contrôle público;

b.4) Extratos bancários.

Observações - Os documentos especificados nos itens b.1), b.2), b.3) e b.4) têm de ser examinados de forma com- 
binada, a fim de assegurar que os seguintes limites legais, relativos aos recursos do Fundo, sejam respeitados:

- um mínimo de $50 \%$ tem de ser aplicado em despesas de capital;

- um mínimo de $20 \%$ em educação; e

- um mínimo de $10 \%$ em saúde.

O volume de trabalho que representa êsse exame combinado e a existência de limites uniformes a serem observados em todos os casos denotam a necessidade e a aplicabilidade do uso de computação eletrônica nessa área.

Os estudos para a introdução do processamento de dados em tais operações, a curto prazo, já se encontram perto do seu término.

\section{2a, $3^{a}$ e 4 a DIRETORIAS TÉCNICAS}

Natureza do Trabalho Executado - Estas Diretorias Técnicas cobrem tôda a área da Administração Federal Direta. Cada uma delas tem, sob sua responsabilidade, um determinado número de Ministérios e as diversas Repartições da Administração Direta.

Além de inspeções in loco, efetuadas por estas Diretorias, cujos resultados são analisados para proposição das medidas necessárias, o contrôle levado a efeito pelas mesmas, na Sede do Tribunal, compreende as seguintes operações:

\section{1 - Contrôle da Execução do Orçamento}

a) Abertura de fichas de contrôle financeiro e orçamentário para as dotações contidas no orçamento federal, de acôrdo com as suas várias subdivisões;

b) Lançamentos em tais fichas, de acôrdo com os dados contidos nos seguintes documentos submetidos ao Tribunal:
b. 1) Balancetes mensais;
b.2) Comunicações relativas a passes e repasses de fundos para utilização pelas autoridades compe- tentes, na execução do orçamento;

c) Acompanhamento da execução do orçamento, por meio da comparação dos dados contidos nos documentos mencionados acima com a programação financeira de desembôlso submetida por cada repartição. 
2 - Exame das contas submetidas ao Tribunal por todos os ordenadores de despesas e responsáveis por dinheiros públicos, de acôrdo com os aspectos legais e contábeis específicos, baseados nos seguintes documentos:

a) "Rol de Ordenadores de Despesas" submetido ao Tribunal pelo Contrôle Interno;

b) "Demonstrativos de Aplicação dos Créditos";

c) "Certificado de Auditoria", emitido pelo Contrôle Interno;

d) Pareceres das autoridades administrativas competentes.

3 - Exame de Contratos e Licitações.

5 a DIRETORIA TÉCNICA

Natureza do Trabalho Executado - esta Unidade tem sob sua responsabilidade o exame de tôdas as matérias referentes à concessão de aposentadoria, reformas e pensões.

Um total de aproximadamente 16.976 processos foi examinado por esta Unidade no ano de 1970.

Além do exame do cálculo do valor a ser pago mensalmente, em cada caso, o trabalho implica o estudo meticuloso, do ponto de vista legal, de cada caso em si, em razão da abundante legislação sôbre a matéria.

A decisão da Côrte, em cada caso, é devidamente anotada para fins de contrôle, bem como de informação jurisprudencial.

Observação - A complexidade da análise jurídica que implica o trabalho acima descrito e a grande subjetividade das demais tarefas executadas nesta área, envolvendo processos trodelaboração mental mais amplos, tornam mais difícil a introdução da automatização em tais operações.

\section{6a E 7a DIRETORIAS TÉCNICAS}

Diretorireza do Trabalho Executado - o trabalho destas duas dades compreende o exame das contas de tôdas as EntiFundaçõe Administração Indireta, tais como Emprêsas Públicas, Públiçōes, Emprêsas de Economia Mista, Emprêsas de Serviços icos, Autarquias e Entidades Parafiscais.

dades número de processos referentes às contas dessas entiexaminados em 1970 alcançou o total de 1.059. 
Inspeções in loco também são levadas a efeito na área sob a responsabilidade destas Diretorias, para os mesmos fins mencionados nos casos anteriores.

O trabalho desenvolvido pelas $6^{\text {a }}$ e $7^{\text {a }}$ Diretorias está baseado no exame dos seguintes documentos, variando de acôrdo com a natureza das entidades controladas:

- Balanços Financeiros Anuais; Balanços Patrimoniais; Balanços Econômicos; e Balanços Orçamentários;

- Demonstrativo de Variação de Lucros e Perdas;

- Demonstrativo Analítico das Contas do Balanço;

- Inventário Geral;

- Autorizações para Alienação de Ativos Fixos;

- Extratos Bancários;

- Relatórios Administrativos;

- Parecer do Conselho Fiscal;

- Certificado de Auditoria emitido pelo Contrôle Interno do Ministério ao qual a Entidade se encontra vinculada.

No caso específico de autarquias, os seguintes documentos básicos são também examinados:

- Orçamento Anual;

- Demonstrativo de Execução Orçamentária;

- Relatório do Dirigente da Entidade.

Brasilia, julho de 1971.

Observação: Tese apresentada perante o VII Congresso Internacional das Instituições Superiores de Contrôle das Finanças Públicas. Canadá Montreal. Setembro de 1971.

FEDERATIVE REPUBLIC OF BRAZIL

Subject II

\section{ELECTRONIC DATA PROCESSING AND OTHER TECHNOLOGICAL AIDS}

The need for computerization in auditing has its roots in four facts: the ever-growing complexity of audit, the slow pace of its present services, in which we find a minimum of efficiency and a maximum of time-consuming processes, the lack of accuracy of such processes, and the economy of brain-power that will for sure arise from the implementation of new methods. 
This holds good in the particular case of Brazil, may be of all countries in which automation has not found its way into auditing.

There are, of course, some fields where the use of computers is still in the cradle, and its results very doubtful. The literary computer is an example in point. It is only too natural that attempts at generating poetry, for example, have revealed the impossibility of producing sentences with different structures from those analysed. Even the best poems - we are told - produced among thousands were less interesting in their own right than for the fact that in their illogicality and obscurity they lead back to traditional aesthetic problems.

On the other hand, sixty-four participants from nine countries who met last year in Cambridge for a three-day symposium heard and discussed more than 30 short papers on current research projects, and came to a conclusion that may be significant to the uses of computer programmes in the field of auditing as related to legal principles applied to budgets, official reports, dossiers, etc. viz., the logical precision demanded of legal utterance is admirably suited to the form of syntactical analysis for computer processing.

So, it is no wonder that most computer programmes can give the auditor the capability of performing such important tasks as computing, verifying, scanning, comparing, selecting, summarizing, and sampling through use of the speed and accuracy of the computer.

As to economical aspects, suffice it to say that the analysis lifo computer used by The San Francisco Regional Oifice, California, has shown that a programme for the control over payMeds to physicians for nursing home visits under the Federal US\$ $\$$ are and State Medicaid cost about US $\$ 1.600$ as against The 9.600 , that is, the savings were estimated at US $\$ 8.000$. would be in the same operation in terms of conventional methods We in man-days absolutely prohibitive.

two We have been able to evaluate the differences of time in they are: accounts of the control intended to check whether or not the for application 4.122 municipalities and their estimated plans the followin of the amounts of the federal aid to be granted in month and year are overdue takes, at the present time, about a what and a half, which means that we never know in due time about ten be known. Well, a computer will give us the answer in out ten minutes after the deadline is reached; b) the control 
of the amounts paid by order of the Court Audit to the municipalities takes three officials all the year round; now, the computer will spend about 24 hours a year on the same task.

Accuracy largely depends on the quality of the data fed to the computer, and this, in its turn, lies in the qualifications of the personnel that prepare such data. As the saying goes in America, if we feed the computer with trash it will give us back trash.

No auditor must have more than a general knowledge of the computer, its needs and problems. There is no need at all for him to know the operations involved in the functioning of the computer.

Notwithstanding, it goes without saying that the help of skilled men cannot be discarded from the operations of the computer in order to feed it rightly and receive from it accurate responses.

In his remarkable "Management Planning for Data Processing", Dick H. Brandon asserts that more than $40 \%$ of all systems of data processing in the United States are utter failures, and most of such failures are to be ascribed to the incapacibility of administrative tops to back the activity of data processing or to take interest in the question.

Here are some of the crucial questions that this matter raises: Is the electronic data processing the most adequate to a given case? What economical consequences will arise from its implementation? How is its installation and operation to be planned? What kind of information is the administration in need of in order to put the new process into operation? Who is to take care of such problems?

Hardware will certainly fail if software is not present.

As a matter of fact, in the particular case of The Brazilian Court of Audit it would be foolish to think of buying a computer. It costs a lot of money, it would be idle most of the time, and it would rapidly become old-fashioned. The right solution is to rent the services of a company in good repute. This is what we have done.

All service units of this Court will greatly benefit by the introduction of a microfilm system intended to replace the file system of thousands of dossiers, documents, and papers of $\mathrm{va}^{-}$ rious description. This means that an average sheet of paper of $33 \mathrm{cms}$ by $22 \mathrm{cms}$ will be reduced at least 40 times its size, which will save a corresponding space in the files, that is, 8.3
$\mathrm{mms}$ by $5.5 \mathrm{mms}$. 
With respect to the utilization of electronic data processing in the Brazilian public administration, the following points are worth mentioning:

In 1964 a public enterprise bearing the initials "SERPRO" (Federal Service for Data Processing) was created, primarily to render services to the Finance Ministry with it remains connected.

The scope of action of this enterprise has been considerably enlarged, and it is now allowed to render services, under contract, to any other federal, state or municipal agencies.

In the area of the Finance Ministry all the work in the Revenue Division concerning the charging, collection and accounting processing of the federal taxes is already being electronicaly computed by the enterprise in question.

The "SERPRO" presently processes over $60 \%$ of the payrolls of all the federal agencies. A great expansion in its activities is expected owing to the considerable number of technical surveys being conducted upon request of government bodies interested in the use of computing aid.

It is also important to mention that the "SERPRO" will shortly be operating a "National Training Center for Computation", which will have as its main objective the administration of courses on programming, analysis, and all other skills pertaining to electronic data processing for public employees, university graduates and other qualified persons, in order to meet the increasing demand for specialized labour in that field.

In the area of the Indirect Administration it should be pointed out that some entities of great importance and high volume of work have installed their own processing systems, most of them both for internal administrative purposes and for external operational purposes:

Among these, the most important are the following:

- the "National Institute for Social Security" (INPS)

- the "Federal Savings Bank" (CEF);

- the "Federal Railway Network" (RFFSA);

- the "Bank of Brazil";

- the "Central Bank of Brazil";

- the "Brazilian Enterprise for Tele-Comunications" (EMBRATEL); and

- the "Brazilian Petroleum Company" (PETROBRAS). 
The external control of the public finance in Brazil is ultimately incumbent upon the National Congress with the aid of the Court of Audit, which is organized on a board basis and is composed of nine Ministers who take the decisions by voting.

The Brazilian Institution regards the introduction of data processing in its services as an urgent necessity in order to cope with the increasing amount of its work and to secure high standards of efficiency, speed, exactness and economy.

Preliminary studies are already being conducted, both by the "National Service for Data Processing (public enterprise) and by a private company. Electronic computing will expand gradually until it can cover all the areas suitable to automation.

The General Secretariat of the Court, in charge of the execution of all the operations concerning the control of the public finance, is divided into several units, according to the nature of the services executed in them, and comprises one Administrative Division and Seven Technical Divisions.

\section{ADMINISTRATIVE DIVISION}

Within the Administrative Division, besides the Personnel Section, which already has the payroll processed by the "Federal Service for Data Processing" mentioned above, the "Distributing Center" deserves special attention.

The following points are worth mentioning concerning it:

Nature of the work performed - receiving, numbering, recording and distributing all dossiers and documents submitted to the Court; dence;

- remittance of all dossiers; documents and correspon-

- recording of the movement of all dossiers and documents within the Court;

- supply of information to any person or goverment body, as well as to the other units of Court, concerning the development of all dossiers, and the processing of any documents submitted or sent to the Institution, and its exact location, at any time, within the Court. The volume of this work attained in 1970 a total of 137.378 units.

Owing to the volume of data manipulated in the "Center", deriving from the high number of documents submitted to the 
Court, it could be benefited by a drastic reduction on the amount of man/hours necessary for their proper handling by means of electronic computing.

Data processing is intended to be introduced here on a short-term basis.

The preliminary analysis being made indicates that the use of automation in this unit could immediately benefit all other units of the Court, especially with respect to the control on the deadline for submission of certain dossiers, as is the case of 4.122 municipalities which have to render their accounts until April 30 , under the penalty of suspension of the delivery of the federal fund granted to them until such documents are sent. (See item concerning Technical Division I).

So far, the identification of all municipalities which do not comply with this demand in due time for the ordering of the necessary measures has been jeopardized, in many cases, by the lack of the efficient means to manipulate such a great number of dossiers, and the respective data, at a reasonable speed.

\section{TECHNICAL DIVISIONS}

Each of the seven Technical Divisions is assigned an area of the public administration subject to the external control of the Court of Audit.

Except for Technical Division I, which is in charge of the control of special federal funds given to the States, to the Federal District, municipalities and Federal Territories, and for Technical Division V, which deals with retirement and death pensions, the remaining five Divisions are concerned with areas either of direct or indirect federal administration.

TECHNICAL DIVISION I

in Nature of the work performed - This Division is basically in charge of the control on the amounts deducted from the aggregate of the federal collection of certain taxes, which make up the "Participation Fund of the Municipalities", and the "Participation Funds of the States, of the Federal District and the Federal Territories".

It should be pointed out that, besides controlling the application of these amounts, the Court of Audit also has the responsibility of establishing the percentages of the Fund due to 
each Municipality, State or Territory, and ordering their release by the Bank of Brazil, an official institution.

This mission, conferred upon the Court by the Federal Constitution, goes far beyond its regular controlling action, and represents an exception to its ordinary capacity.

Besides on-the-spot inspections carried out by this unit, the work performed by it, at the Seat of the Court, comprises the following basic operations:

1 - Establishing the percentages and ordering the release of the amounts

a) calculating the percentages due to each Municipality (Brazil has 4.122$)$, State (23 in number), and Territory (3), based on the population, area, and per capita income of each ot them;

b) informing the Bank of Brazil, until December 31, the percentages to be observed in the monthly delivery of the amounts due to each unit.

\section{2 - Controlling the application of the "Fund"}

a) ordering the Bank of Brazil to suspend the delivery of the amounts due to those units that do not render their accounts referring to the application of their shares of the "Fund", as well as their estimated plan for application of the amounts to be granted in the forthcoming year, until April 30.

b) examining the following documents referring to each of the 4.122 units mentioned in item 1a:

b.1) "Annual Financial Statement"; "Annual Statement of Assets and Liabilities"; and "Annual Budgetary Statement" with the respective "Detailed Sheets of Budgetary Execution".

b.2) "Statement of the Execution of the Plan for Application of the Resources from the "Fund";

b.3) Copy of the "Annual Detailed Statement of the Application of the Resources from the "Fund" published in the local press for control by the public;

b.4) Bank Statements.

Observations - The documents specified in itens b.1, b.2, b. 3 and b. 4 have to be examined in a combined way in order 
to secure that the following legal limits concerning the resources from the "Fund" are respected:

- a minimum of $50 \%$ has to be spent on "capital" items;

- a minimum of $20 \%$ has to be spent on education and

- a minimum of $10 \%$ has to be spent on health items.

The overwhelming amount of work involved in performing this combined examination, and the existence of uniform pattern limits to be observed in all cases denote the necessity and the feasability of using electronic computing in this area.

Studies for the introduction of data processing in such operations on a short-term basis are about to come to completion.

TECHNICAL DIVISIONS II, III and IV

Nature of the work performed - These Tecnical Divisions cover the whole area of the federal direct administration. Each of them is assigned a number of Ministries and the many Agencies of the direct administration within their respective frameworks.

Besides the in loco inspections carried out by these Divisions, the results of which are analysed for the proposal of the necessary measures, the control performed by them at the Seat of the Court comprises the following typical operations:

\section{1 - Control of the execution of the budget}

a) opening "Financial and Budgetary Control Records" for the appropriations contained in the Federal Budget, according to their various subdivisions;

b) making the necessary entries on these records according to the data contained in the following documents submitted to the Court:

\section{a.1) "Monthly Financial Statements";}

a.2) Communications concerning the allocation and reallocation of funds for utilization by the proper authorities in the execution of the budget.

c) following-up the execution of the budget by means of comparison of the data contained in the documents mentioned above with the "Financial Programming for Disbursement" submitted by each Agency. 
2 - Examination of the accounts submitted to the Court by all officials responsible for expenditures and by those who manipulate public property, according to the legal and accounting aspects involved, based on the following documents:

a) "Roll of Officials Responsable for Expenditures" submitted to the Court by the Internal Control;

b) "Statement of Application of the Credits";

c) "Audit Certificate", issued by the Internal Control;

d) Opinion of the proper administrative authorities.

3 - Examination of public contracts and bids.

TECHINICAL DIVISION V

Nature of the work performed - This unit is in charge of the examination of all matters referring to the granting of civil and military retirement pensions and death pensions, before the respective dossier are submitted to the Court for the judgment of their legality.

A number of 16.976 dossiers were examined by this Division in 1970 .

Besides the examination of the calculation of the amount to be paid monthly, in each instance, the work in this Division involves a meticulous study, from the legal point of view, of each case owing to the exceedingly abundant legislation on the matter.

The decision of the Court in each case is recorded for purposes of control, as well as of jurisprudential information.

Observation - The complexity of the legal analysis described above and the subjectiveness of the work performed in this area, all of it dependent on wider mental processes, make it the most difficult to the introduction of automation.

\section{TECHNICAL DIVISIONS VI AND VII}

Nature of the work performed - The basic work of these two Divisions comprises the examination of the accounts of all entities of the indirect administration, such as Public Enterprises. Foundations, Mixed-Ownership Enterprises, Public-Service Companies and "Authorities" as well as "Para-fiscal" Entities. 
The number of dossiers referring to the accounts of such entities examined by these two Divisions and submitted to the Court, in 1970, amounted to 1.059 .

In loco inspections are also carried out in the area under these Divisions, for the same purposes mentioned in the previous cases.

The work performed by Divisions VI and VII is based on the examination of the following documents, varying in accordance with the nature of the controlled entity:

- "Annual Financial Statement"; "Annual Statement of Assets and Liabilities"; "Annual Economic Statement" and "Annual Budgetary Statement";

- "Profit and Loss Variation Statement";

- "Analytic Statements of Balance Accounts";

- "General Inventory List";

- "Authorizations for the Disposal of Assets";

- "Bank Statements";

- "Administrative Reports";

- "Opinion of the Fiscal Council";

- "Audit Certificate" issued by the internal control of the Ministry with which the entity is connected.

In the specific case of "Authorities", the following additional basic documents are examined:

- "Anual Budget";

- "Budget Execution Statement";

- "Report of the Head of the Entity".

Brazil.

Brasilia, July 1971. - Abgar Renault, Court of Audit of

(Traduzido pelo Professor José Sebastião Barreto de Macedo) 
